\title{
Lubrication for High Load Duplex Bearings
}

Federal Manufacturing \& Technologies

R. G. Steinhoff

KCP-613-5983
RECEIVED

SEP 221997

OSTI

Published August 1997

Topical Report

Approved for public release; distribution is unlimited.

DISTRIBUTION OF THIS DOCUMENT Is UNLMTED th

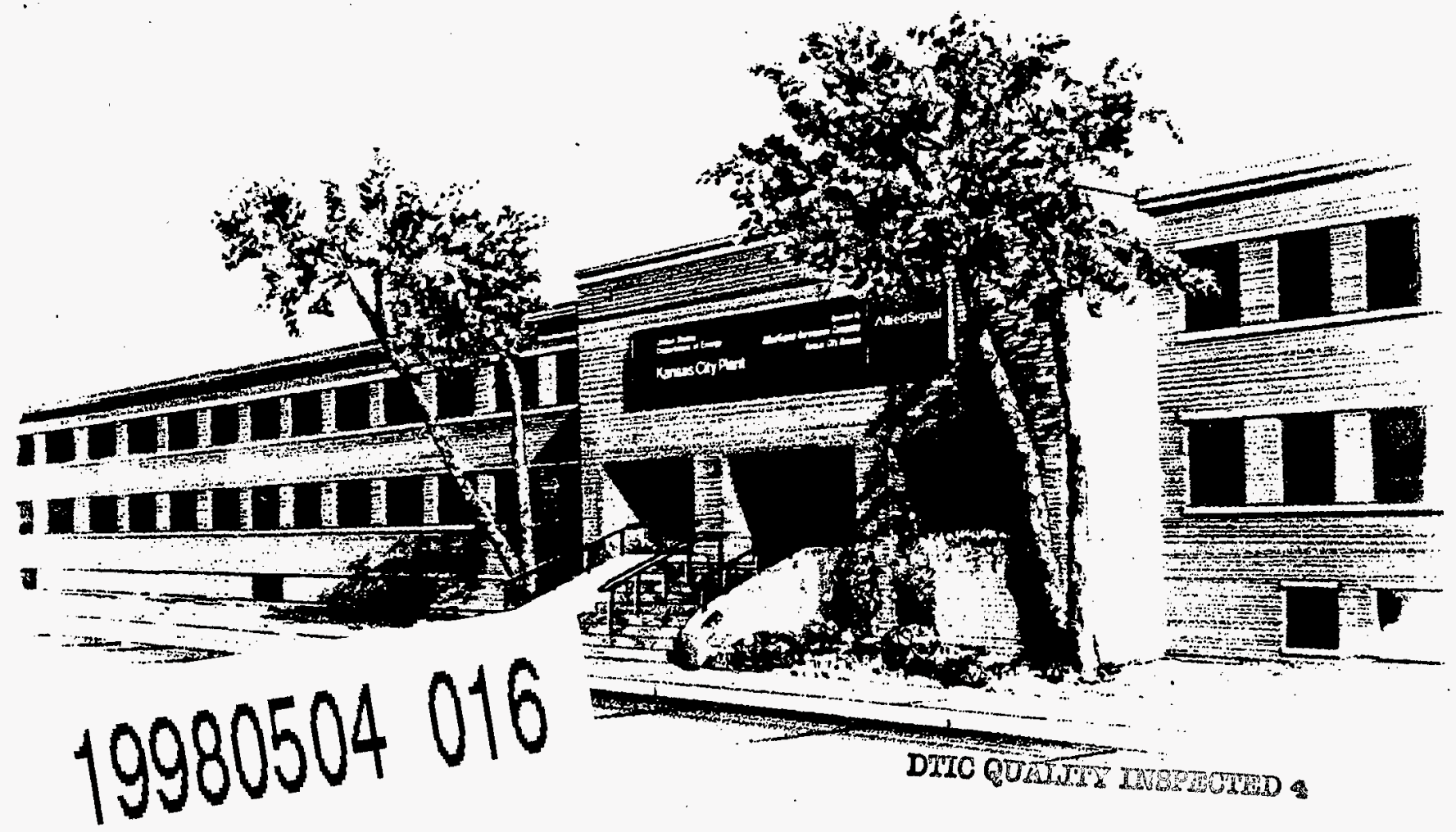




\section{DISCLAIMER}

This report was prepared as an account of work sponsored by an agency of the United States Government. Neither the United States Government nor any agency thereof, nor any of their employees, makes any warranty, express or implied, or assumes any legal liability or responsibility for the accuracy, completeness, or usefulness of any information, apparatus, product, or process disclosed, or represents that its use would not infringe privately owned rights. Reference herein to any specific commercial product, process, or service by trade names, trademark, manufacturer, or otherwise, does not necessarily constitute or imply its endorsement, recommendation, or favoring by the United States Government or any agency thereof. The views and opinions of authors expressed herein do not necessarily state or reflect those of the United States Government or any agency thereof.

All data prepared, analyzed and presented has been developed in a specific context of work and was prepared for internal evaluation and use pursuant to that work authorized under the referenced contract. Reference herein to any specific commercial product, process or service by trade name, trademark, manufacturer, or otherwise, does not necessarily constitute or imply its endorsement, recommendation, or favoring by the United States Government, any agency thereof or AlliedSignal Inc.

Printed in the United States of America.

This report has been reproduced from the best available copy.

Available to DOE and DOE contractors from the Office of Scientific and Technical Information, P. O. Box 62, Oak Ridge, Tennessee 37831; prices available from (615) 576-8401, FTS 626-8401.

Available to the public from the National Technical Information Service, U. S. Department of Commerce, 5285 Port Royal Rd., Springfield, Virginia 22161. 
KCP-613-5983

Distribution Category UC-706

Approved for public release; distribution is unlimited.

\section{LUBRICATION FOR HIGH LOAD DUPLEX BEARINGS}

R. G. Steinhoff

Published August 1997

Topical Report

R. G. Steinhoff, Project Leader 


\section{Contents}

Section

Page

Abstract

Summary

1

Discussion

3

Scope and Purpose .......................................................... 3

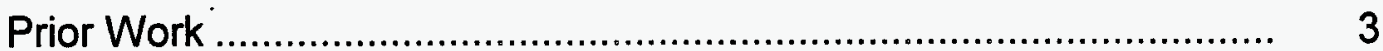

Activity ........................................................................ 4

Tester and Test Procedure ................................................ 4

Baseline Lubricant.................................................... 5

Supercritical $\mathrm{CO}_{2}$ Deposition of Vy.dax ............................ 6

Titanium Carbide $(\mathrm{TiC})$ Coated Balls ............................... 9

Diamond-Like Carbon (DLC) Coated Races ......................... 10

Accomplishments ......................................................... 13 


\section{Illustrations}

Figure

Page

1 Cross Section of a Duplex Bearing ..................................................... 4

2 Bearing Torque Tester................................................................ 5

3 Average Torque Comparison-All.Candidates............................... 5

4 Average Torque Comparison-Supercritical $\mathrm{CO}_{2} N y$ dax

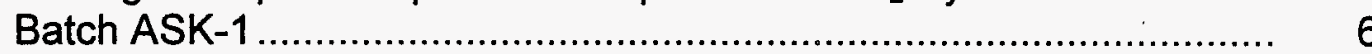

5 Average Torque Comparison-Supercritical $\mathrm{CO}_{2} N y d a x$

Batch ASK-8 .......................................................................... 7

6 Average Torque Comparison-Supercritical $\mathrm{CO}_{2} \mathrm{Nydax}$

Batch ASK-11 .......................................................................... 7

7 Average Torque Comparison-Supercritical $\mathrm{CO}_{2} \mathrm{Nydax}$

Batch ASK-12

8 Average Torque Comparison-Supercritical $\mathrm{CO}_{2} \mathrm{Nydax}$

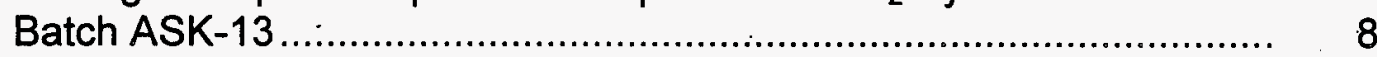

9 Average Torque Comparison-Supercritical $\mathrm{CO}_{2} / \mathrm{Nydax}$

Batch ASK-16 .......................................................................... 9

10 Average Torque Comparison-TIC ............................................. 10

11 Average Torque Comparison-DLC .............................................. 10

12 View of Inner Race With Damaged DLC Coating, 50x Mag.............. 11

13 View of Inner Race With Damaged DLC Coating, 100x Mag............. 11

14 View of Inner Race With Damaged DLC Coating, 1000x Mag........... 12

15 View of Ball From DLC Coated Bearing ........................................ 12

\section{Table}

Number

Page

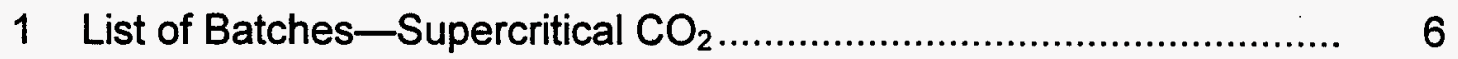




\begin{abstract}
Three ES\&H-compatible lubricants (Environment, Safety and Health) for high load duplex bearing applications were evaluated and compared against trichlorotrifluoroethane (Freon) deposition of low molecular weight polytetrafluoroethylene (PTFE) bearing lubricant extracted from Vydax ${ }^{T M}$. Vydax is a product manufactured by DuPont consisting of various molecular weights of PTFE suspended in trichlorotrifluoroethane (Freon) which is an ozone-depleting solvent. Bearings with Supercritical $\mathrm{CO}_{2}$ deposition of PTFE extracted from $V y$ dax AR/IPA, bearings with titanium carbide coated balls, and bearings with diamond-like carbon races and retainers were evaluated. Bearings with Supercritical $\mathrm{CO}_{2}$ deposition of PTFE from Vydax AR/IPA performed as well as bearings with Freon deposition of PTFE from Freon-based Vydax.
\end{abstract}

\title{
Summary
}

Three ES\&H-compatible (Environment, Safety and Health) lubricants for high load duplex bearing applications were evaluated and compared against Freon deposition of PTFE from $V y d a x^{\top M}$ bearing lubricant. Vydax is a product manufactured by DuPont consisting of various molecular weights of polytetrafluoroethylene (PTFE) suspended in trichlorotrifluoroethane (Freon). Manufacturing of Freon has been curtailed in response to environmental, safety, and health concerns regarding damage to the earth's ozone layer. Exemptions at AlliedSignal Federal Manufacturing \& Technologies (FM\&T) are required in order to use Vydax and Freon.

The high load duplex bearing placed the highest demand on bearing lubrication because of the high contact stresses caused by the large load required to bring the inner races together. This bearing was designed specifically for use in a stronglink C-Module to add a controlled amount of friction in the pattern wheel shaft to correct for over-travel rotation of the pattern wheel due to rebound of the solenoid during high voltage actuation. This problem was designed out of the C-Module as a result of production activities. Hence the need for this type of bearing and evaluations using this bearing were discontinued after 1993. Information from this evaluation is valuable because if a lubricant can pass the demanding requirements of this bearing, the lubricant would most likely be suitable for any bearing application.

Bearings with Supercritical $\mathrm{CO}_{2}$ deposition of Vydax AR/IPA, bearings with titanium carbide coated balls, and bearings with diamond-like carbon races and retainers were evaluated and compared against bearings with Freon deposition of filtered Vydax. 
The results indicate that Supercritical $\mathrm{CO}_{2}$ deposition of Vydax AR/IPA provides nearly the same lubrication effectiveness as Freon deposition of filtered Vydax. Further investigation into determining an optimum process is still needed. Even though Vydax AR/IPA is ES\&H compatible, Freon is still used by DuPont in the manufacture of this product. DuPont will have to cease manufacture of this product but is working on a product that does not require Freon during manufacturing. An evaluation program was being developed with Phasex Corporation to further develop the Supercritical $\mathrm{CO}_{2}$ process, but this was put on hold until a replacement for Vydax that does not use Freon in the process is available. The molecular weight distribution of the replacement material may affect the extraction process using Supercritical $\mathrm{CO}_{2}$.

The bearings with TiC coated balls did not perform adequately for this application, but they may warrant further evaluation for lower load applications.

The results indicate that DLC coated races are not a viable alternative to the high contact stresses seen in the high load duplex bearings. Further investigation may be warranted for low load applications. 


\section{Discussion}

\section{Scope and Purpose}

The objective of this project was to identify potential ES\&H-compatible (Environment, Safety and Health) lubricant candidates for high load duplex bearings and evaluate the most promising candidates against current baselines. This project was undertaken because the current lubricant, filtered Vydax ${ }^{\mathrm{TM}}$, contains PTFE suspended in Freon and requires Freon for dilution during the application process. Manufacturing of Freon has been curtailed in response to environmental, safety, and health concerns over damage to the earth's ozone layer.

Exemptions at AlliedSignal Federal Manufacturing \& Technologies (FM\&T) are required in order to use Vydax and Freon.

The following ES\&H-compatible lubricant candidates were evaluated to replace filtered Vydax for high load duplex bearings:

A. Diamond-like Carbon (DLC) coated races

B. Supercritical $\mathrm{CO}_{2}$ deposition of Vydax AR/IPA

C. Titanium Carbide (TiC) balls

\section{Prior Work}

A high load duplex bearing has two rows of balls, one outer race, two inner races, and no retainer, as shown in Figure 1. The inner races, which have a gap between them when unloaded, are pushed together, which causes the balls to be compressed between the inner and outer races. This stabilizes the bearing with no end play and very little radial play. A high load duplex bearing requires a large force to bring the inner races together. This causes high contact stresses between the balls and races. The high load duplex bearing placed the highest demand on bearing lubrication because of the high contact stresses. This bearing was designed specifically for use in a stronglink assembly C-Module to add a controlled amount of friction in the pattern wheel shaft to correct for over-travel rotation of the pattern wheel due to rebound of the solenoid (also called G-Kick) during high voltage actuation. This problem was designed out of the C-Module as a result of production activities. Hence the need for this type of bearing and evaluations using this bearing were discontinued after 1993. Information from this evaluation is valuable because if a lubricant can pass the demanding requirements of this bearing, the lubricant would most likely be suitable for any bearing application. 


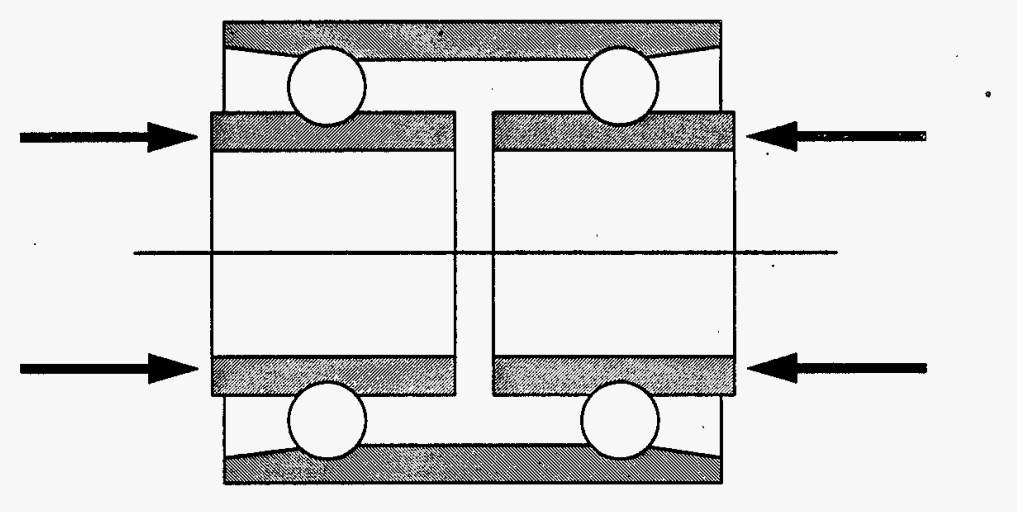

Figure 1. Cross Section of a Duplex Bearing

Stronglink switches designed since 1974 have required lubrication of preloaded bearings in order to operate reliably under various environments. The bearing lubricant of choice in these mechanisms is Freon deposition of low molecular weight PTFE extracted from Vydax. Vydax is a product manufactured by DuPont consisting of various molecular weights of polytetrafluoroethylene (PTFE) suspended in trichlorotrifluoroethane (Freon). The application process consists of siphoning off the soluble portions (low molecular weight PTFE particles) of a settled Freon/Nydax mixture and further diluting the siphoned off portion in Freon. This diluted mixture is then applied to bearings. The Freon is evaporated off, leaving a light film of PTFE "grease" on the bearing. This "grease" is then baked on the bearings. For use in high load duplex bearings, the Vydax mixture is specially filtered in order for the unit to pass in-process requirements.

\section{Activity}

\section{Tester and Test Procedure}

Functional testing of high load duplex bearings was performed on the bearing torque tester. This tester preloads the duplex bearing and rotates it at $0.5 \mathrm{rpm}$ while it records torque data. The tester also can rotate the bearing at $24 \mathrm{rpm}$ without taking torque measurements in order to put cycles on the bearing. Outputs from this tester are Average Torque, Standard Deviation, Range, Max. Torque, and Min. Torque. Figure 2 shows the torque tester. The bearing test procedure is to take measurements on the cycles (revolution) $1,2,5,10,25,50,100,200300$, $400,500,1000,1500$, and 2000. 


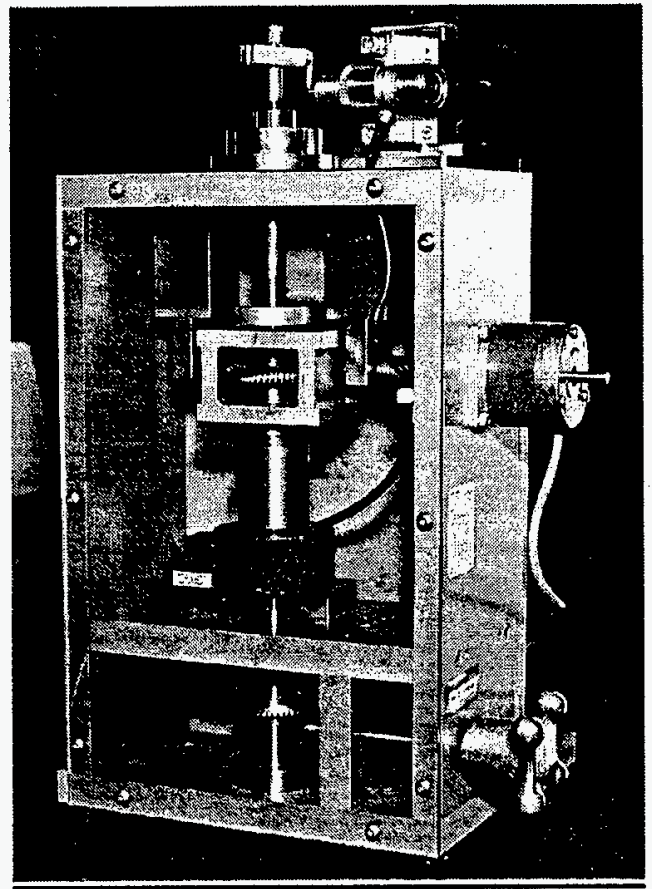

Figure 2. Bearing Torque Tester

\section{Baseline Lubricant}

The baseline lubricant for this bearing is a specially filtered Vydax. In all the figures showing average torque versus number of cycles, average torque of bearings lubricated with filtered Vydax is shown for comparison (Figure 3).

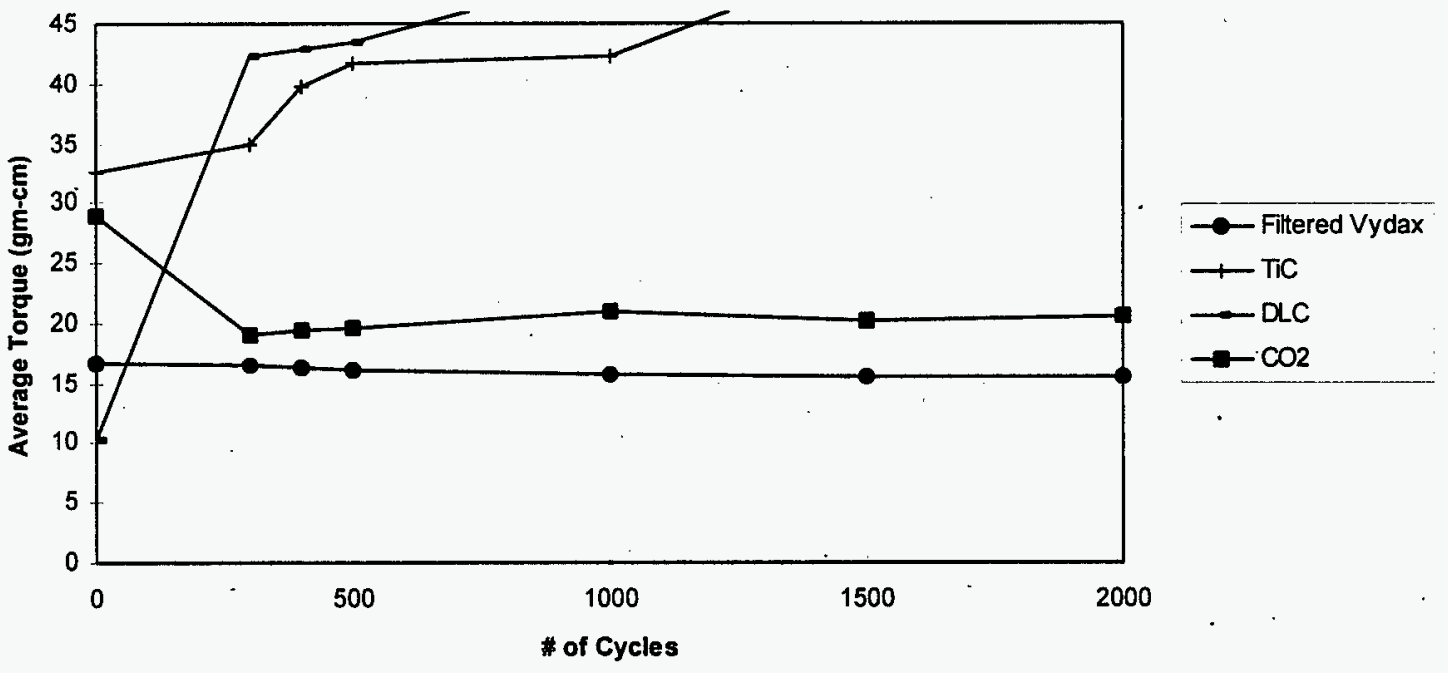

Figure 3. Average Torque Comparison-All Candidates 


\section{Supercritical $\mathrm{CO}_{2}$ Deposition of Vydax}

Processes were developed by Phasex Corporation, Lawrence, MA, for using Supercritical $\mathrm{CO}_{2}$ as a carrier for extracting low molecular weight portions of PTFE from Vydax AR/IPA (PTFE suspended in alcohol) and redepositing the PTFE on a bearing. Seventeen bearings were processed in six batches with varying amounts of PTFE applied to each batch. The processing parameters of each batch were known only by Phasex Corporation due to the proprietary status of their process, but a summary of what is known about each batch is shown in Table 1.

Table 1. List of Batches-Supercritical $\mathrm{CO}_{2}$

\begin{tabular}{|c|l|}
\hline Batch \# & \multicolumn{1}{|c|}{ Description } \\
\hline ASK-1 & Heavy coating on races and balls; excess blown off before torque testing \\
\hline ASK-8 & Uneven application, light on races, thin on balls \\
\hline ASK-11 & Full coverage on races, thinner than ASK-12; only thin coverage on balls \\
\hline ASK-12 & Heavy coating on balls and races; thinner than ASK-1 \\
\hline ASK-13 & Light, even application with occasional small clumps \\
\hline ASK-16 & Light, even application, heavier than ASK-13; lowest concentration of PTFE in $\mathrm{CO}_{2}$ \\
\hline
\end{tabular}

The different batches caused bearings to exhibit different torque performance. The initial batch, ASK-1, had an excessive amount of PTFE. These bearings were "cleaned" by highpressure air to remove the excess lubricant from the bearing. This was discontinued prior to testing subsequent batches. Figure 4 shows average torque is close to the Freon-deposited filtered Vydax. This was surprising considering the excessive amounts of PTFE on the bearings. These bearings were stable throughout the 2000 cycles.

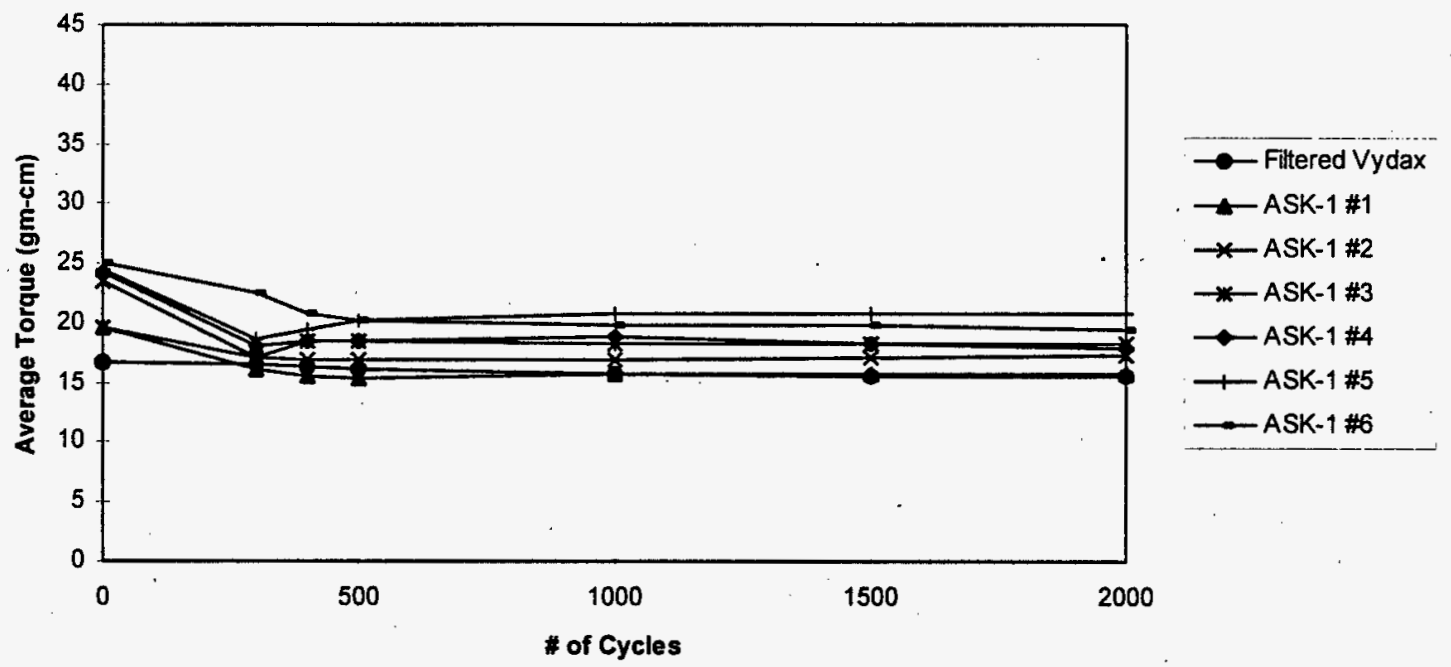

Figure 4. Average Torque Comparison-Supercritical $\mathrm{CO}_{2} N$ ydax Batch ASK-1 
The next batch received was ASK-8. It was quite a bit lighter application and it held up well during testing, as shown in Figure 5. It performed like the Freon-deposited filtered Vydax.

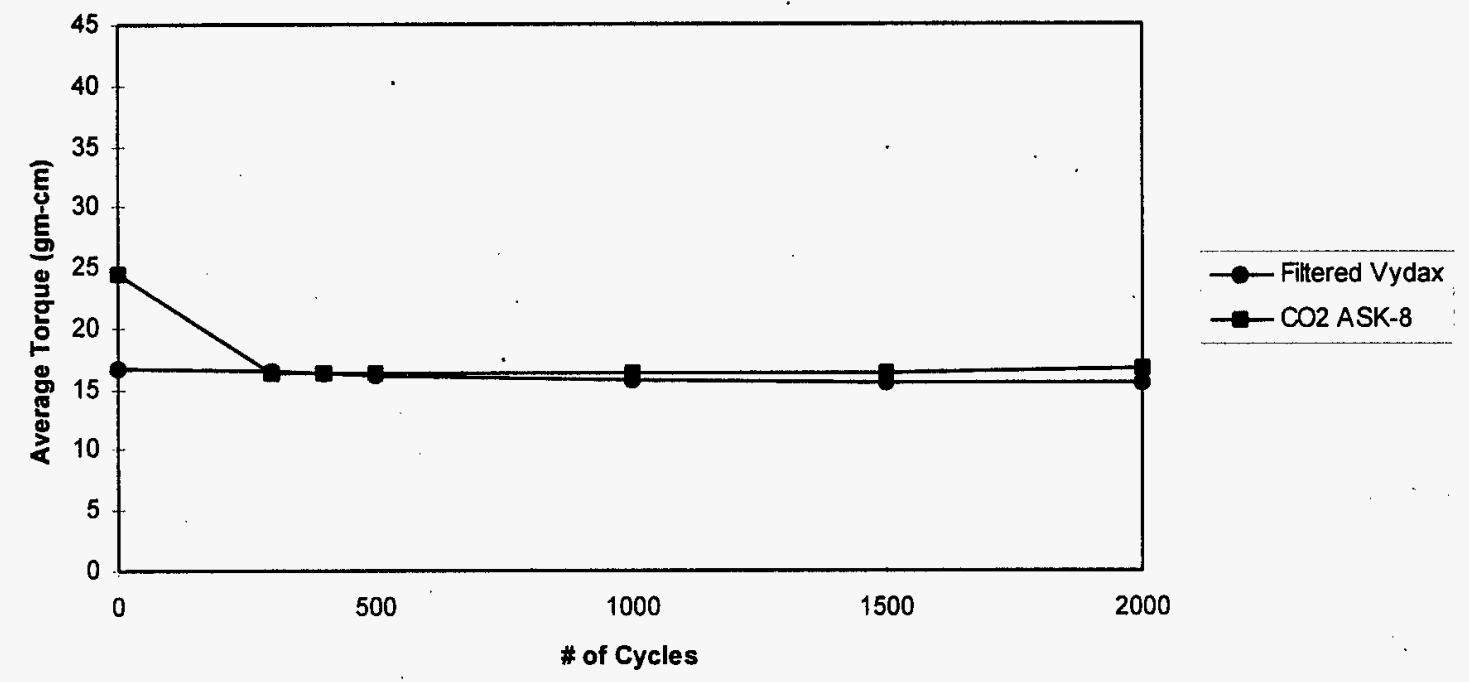

Figure 5. Average Torque Comparison-Supercritical $\mathrm{CO}_{2} \mathrm{Nydax}$ Batch ASK-8

Batches ASK-11 and ASK-12 had heavier coatings, not as heavy as ASK-1: These were not "cleaned" prior to testing. These bearings had high initial torques and took longer to reduce to a stationary level as shown in Figures 6 and 7 . The initial high torques could be due to the balls having to push the large clumps out of the way. Either the "cleaning" process used in ASK-1 was more effective in removing the large clumps than originally thought or the coating of ASK-1 was somehow superior to ASK-11 and ASK-12.

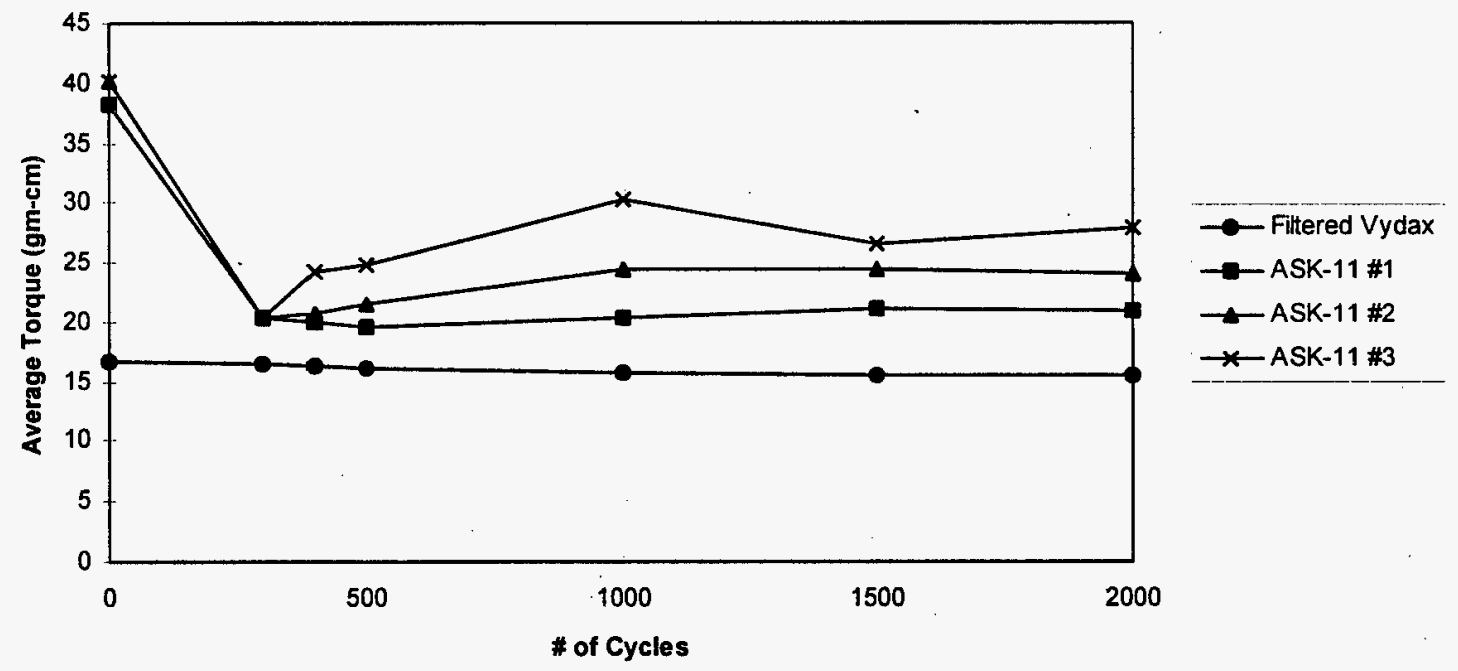

Figure 6. Average Torque Comparison-Supercritical $\mathrm{CO}_{2} / \mathrm{Vydax}$ Batch ASK-11 


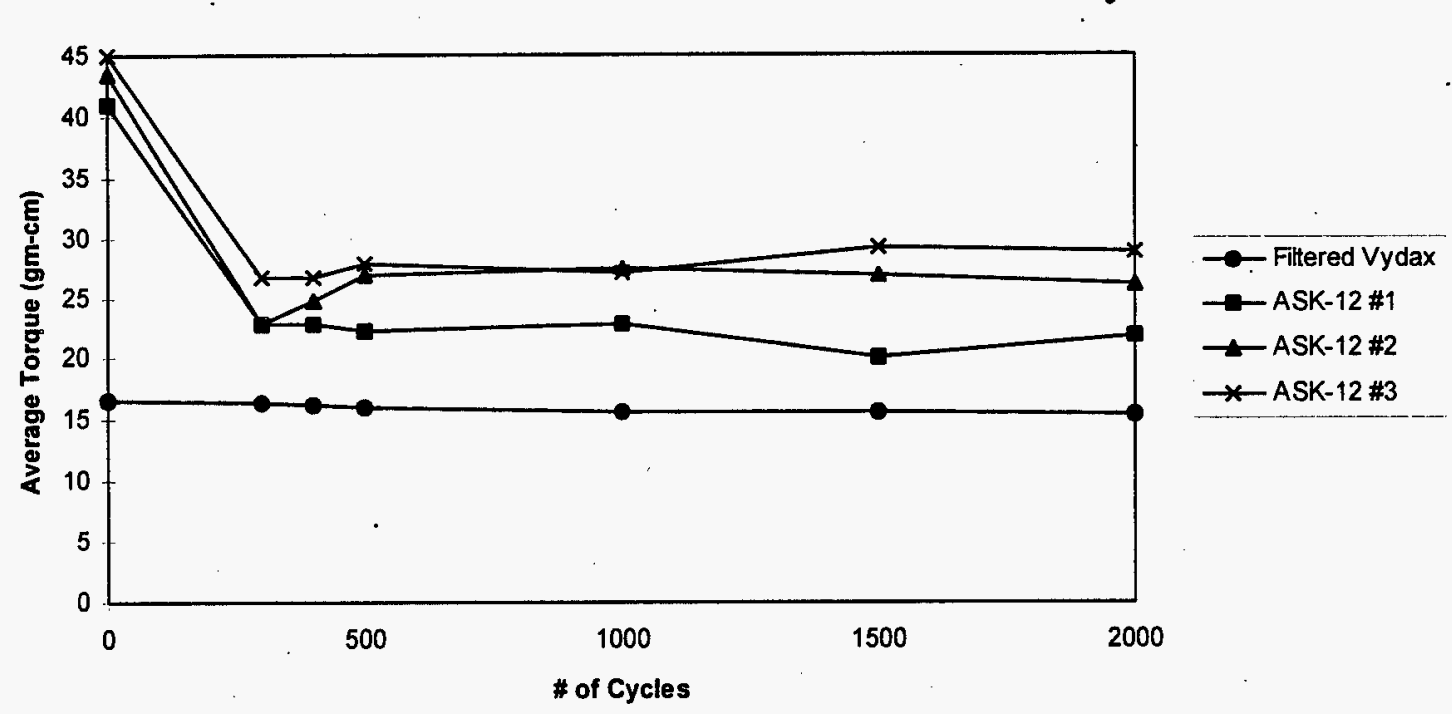

Figure 7. Average Torque Comparison-Supercritical $\mathrm{CO}_{2} \mathrm{Nydax}$ Batch ASK-12

Based on the results of ASK-11 and ASK-12, the batches ASK-13 and ASK-16 had reduced amounts of PTFE deposited and the molecular weight of the PTFE deposits were lower. This resulted in average torques very close to the Freon-deposited filtered Vydax as shown in Figures 8 and 9 .

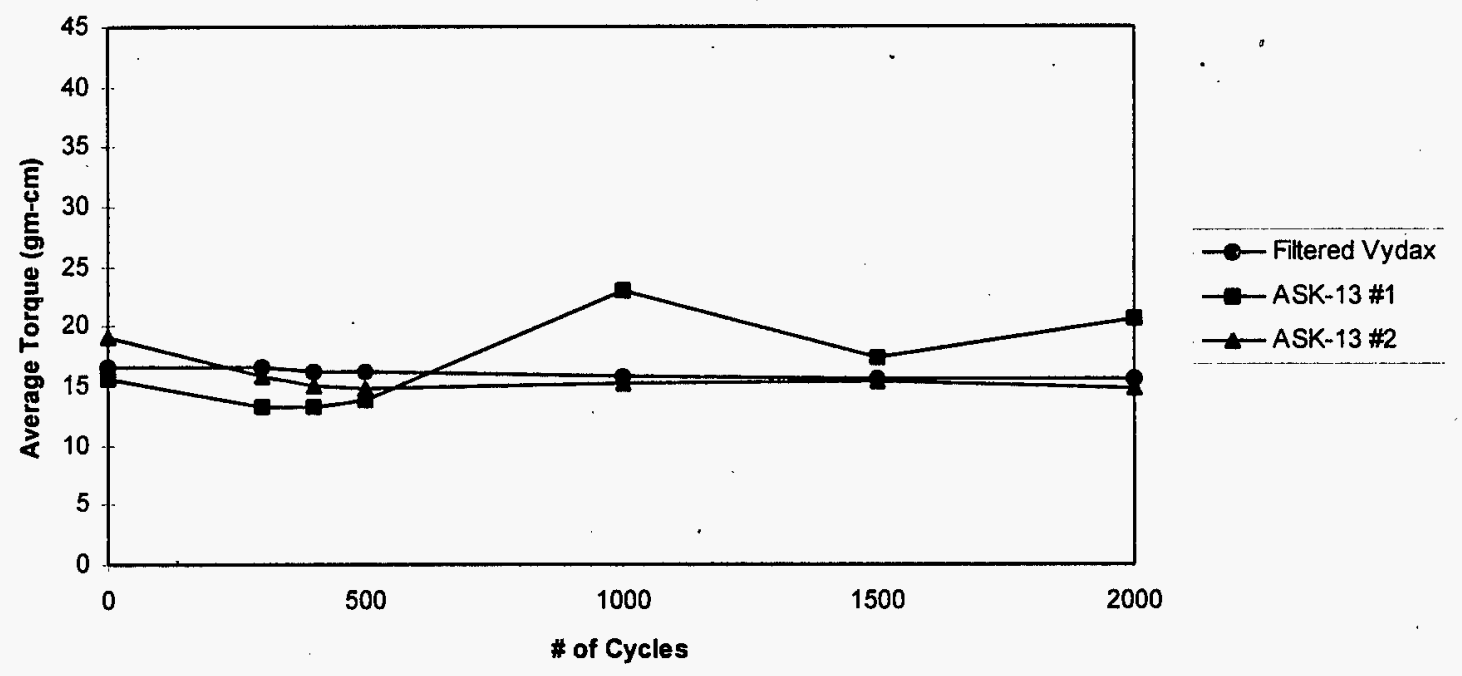

Figure 8. Average Torque Comparison-Supercritical $\mathrm{CO}_{2} N y$ dax Batch ASK-13 


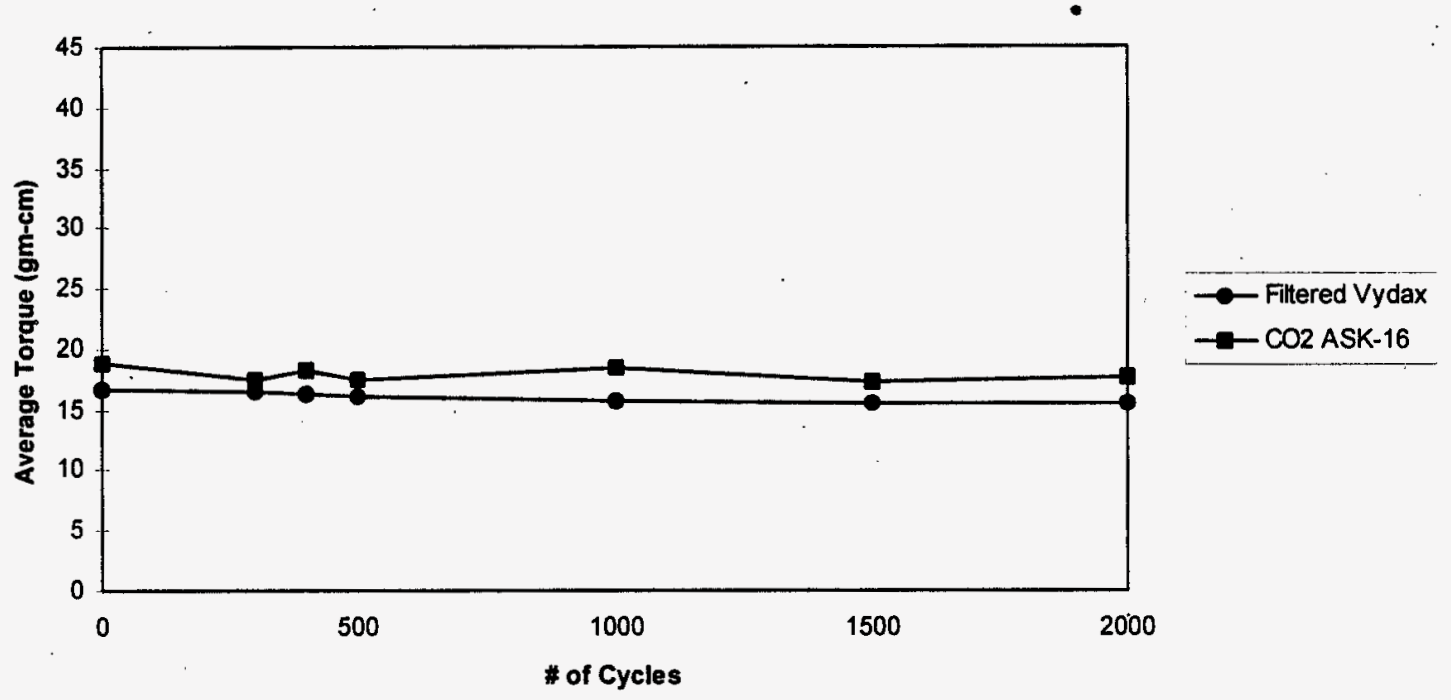

Figure 9. Average Torque Comparison-Supercritical $\mathrm{CO}_{2} \mathrm{Nydax}$ Batch ASK-16

The average torque results as shown in Figures 3-9 indicate that Supercritical $\mathrm{CO}_{2}$ deposition of Vydax provides nearly the same lubrication effectiveness as Freon-deposited filtered Vydax. Further investigation into determining an optimum process is still needed. Even though Vydax AR/IPA is ES\&H compatible, Freon is still used in the manufacture of this product. DuPont will have to cease manufacture of this product but is working on a product that does not require Freon during manufacturing. An evaluation program was being developed with Phasex Corporation to further develop this process, but this was put on hold until a replacement for Vydax that does not use Freon in the process is available. The molecular weight distribution of the replacement material may affect the extraction process using Supercritical $\mathrm{CO}_{2}$.

\section{Titanium Carbide (TiC) Coated Balls}

Bearings with TiC coated balls were obtained and tested. The results of the torque versus number of cycles, as shown in Figure 10, revealed that the TiC coated bearings started out with higher average torque and stayed somewhat stable through 300 cycles. After that, they degraded quickly. These bearings did not perform adequately for this application, but they may do well for a lower load application. One downside to this type of bearing is that they are extremely expensive. 


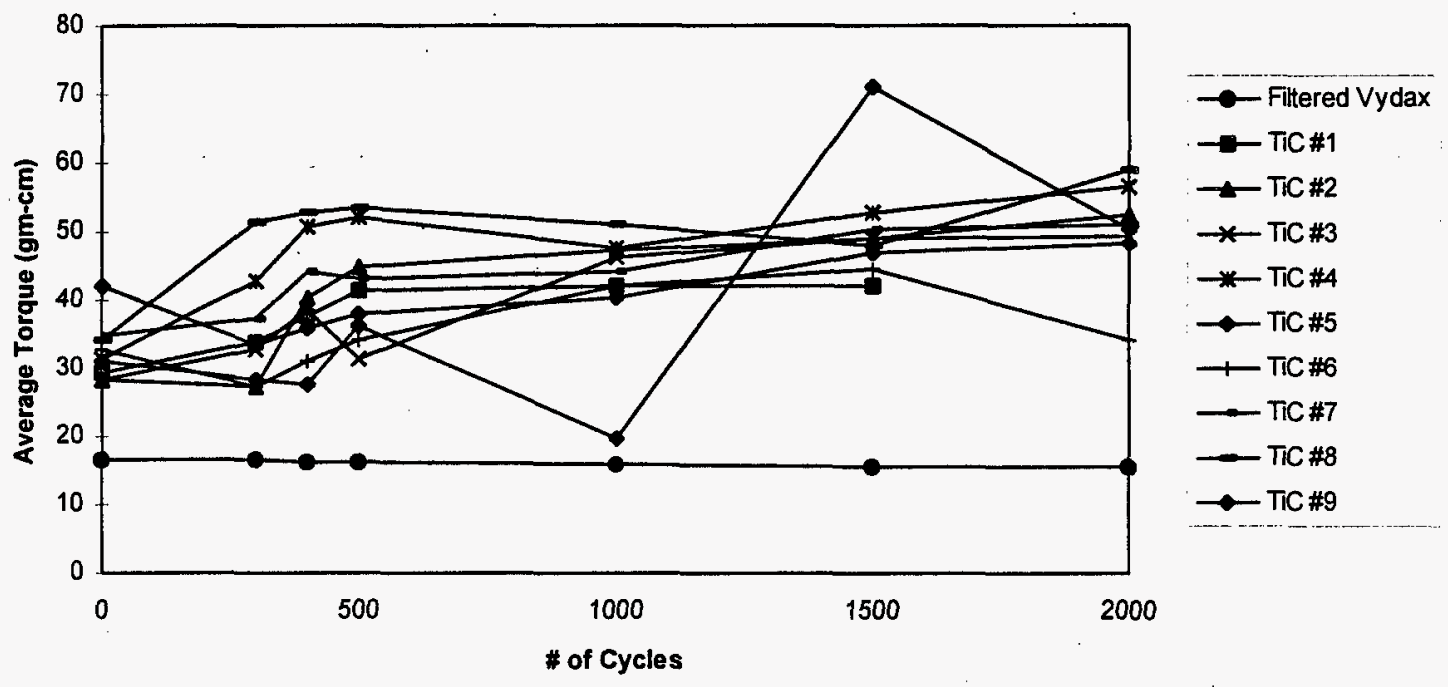

Figure 10. Average Torque Comparison-TiC

\section{Diamond-Like Carbon (DLC) Coated Races}

Diamonex Corporation coated inner and outer races of five disassembled high load duplex bearings with 3000 angstroms of diamond-like carbon using ion beam coating process. One of the bearings was reassembled at FM\&T and tested. Results of the torque versus number of cycles is shown in Figure 11. The bearing torque started out low but immediately increased to unacceptable levels. Scanning electron microscopy (SEM) examination revealed that the coating was fractured and delaminated from the substrate as shown in Figures 12-14.

Figure 12 shows an overall view of the inner race. The DLC is clearly shown to be damaged at the edge of the race where the 180-pound loading of the ball occurred. Figures 13 and 14 are enlargements of this same area. Figure 15 shows one of the ball bearings with DLC adhered to the surface.

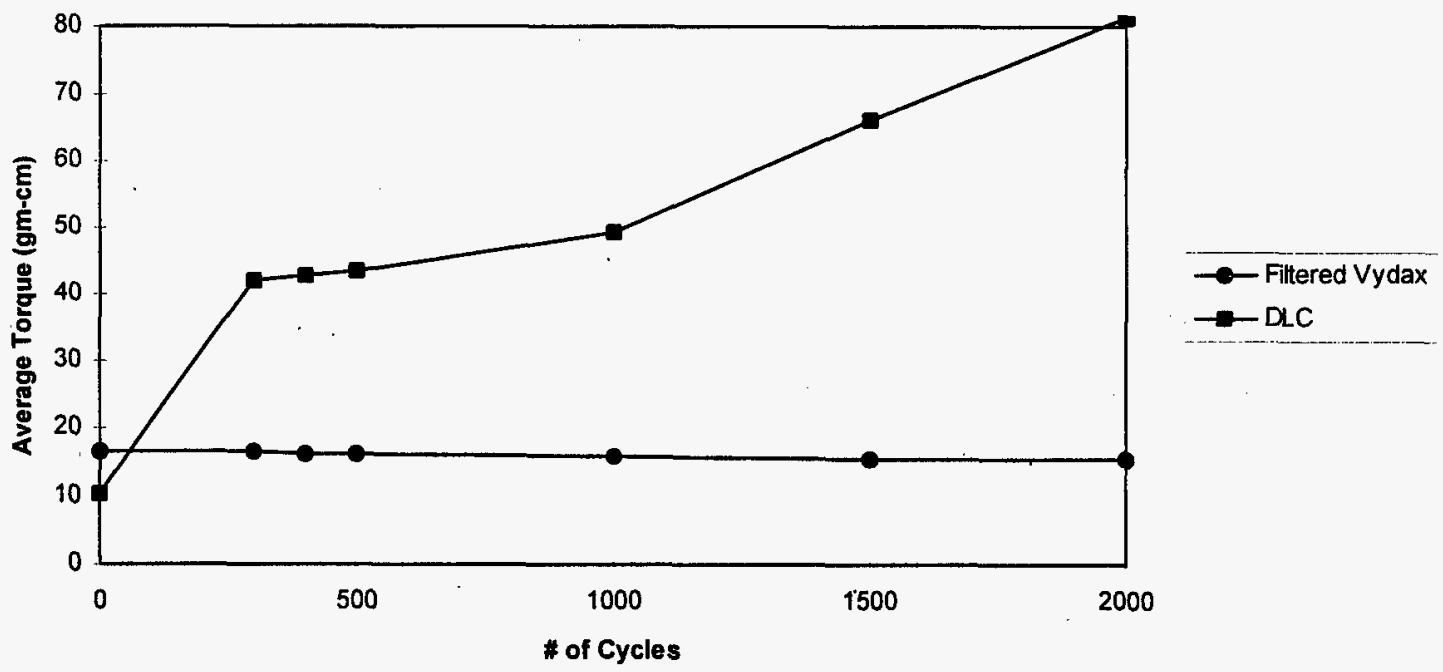

Figure 11. Average Torque Comparison-DLC 



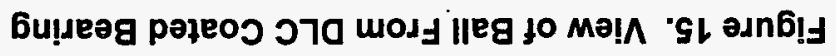

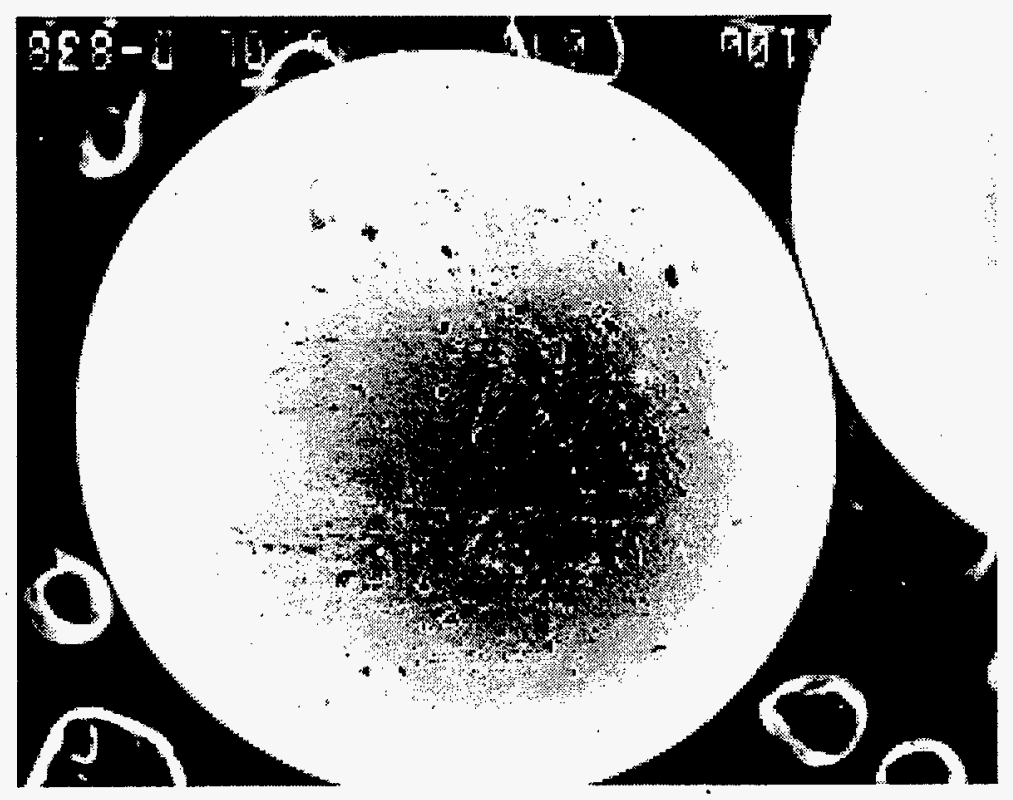

-6ew X0001

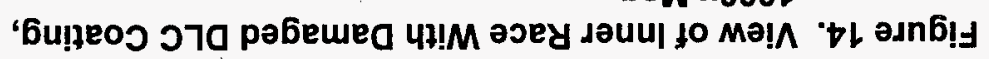

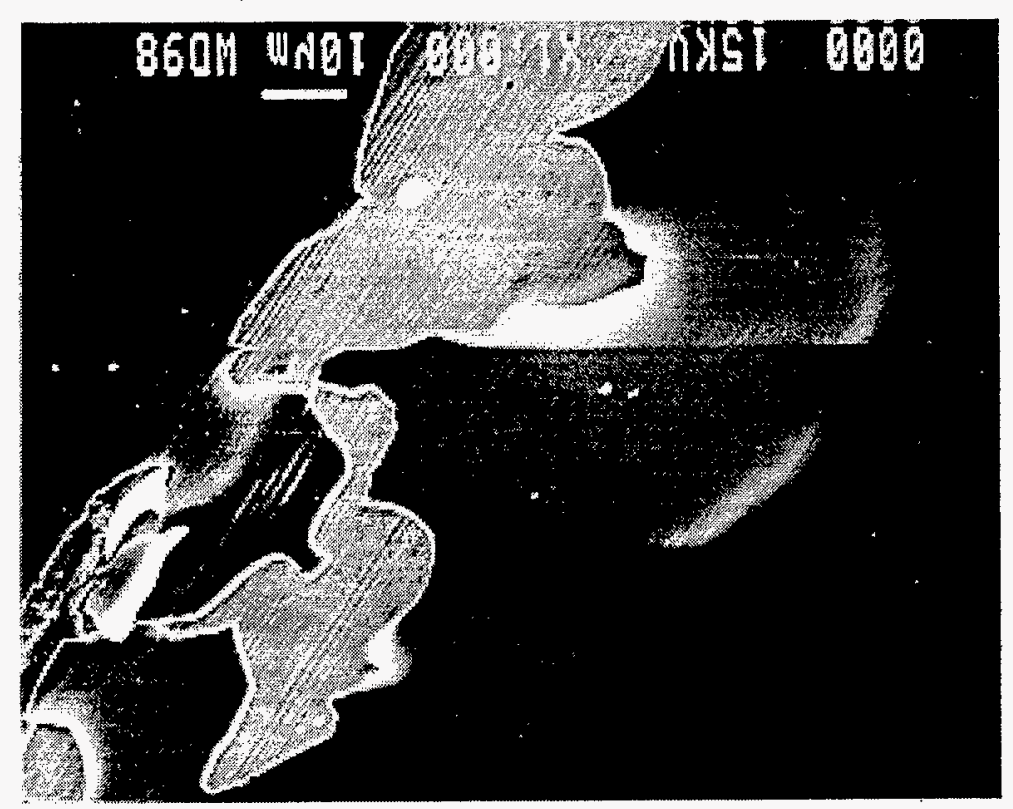




\section{Accomplishments}

Three lubricant candidates for high load duplex bearings were evaluated and compared against filtered Vydax lubricant which is the current baseline. Only Supercritical $\mathrm{CO}_{2}$ deposition of Vydax performed as well as the baseline. This candidate shows great promise as a viable replacement for the ES\&H-unfriendly filtered Vydax process due to the fact that the low molecular weight portions of PTFE can be extracted by the Supercritical $\mathrm{CO}_{2}$ process and be redeposited on bearings. Bearings with $\mathrm{TiC}$ coated balls showed some promise, but not in high load applications. Bearings with DLC coated races and retainers are susceptible to cracked coating and subsequent delamination due to high contact stresses. 
M97054397

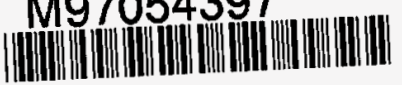

Report Number (14)_KCP- $-6 / 3-5983$

Publ. Date (11) 199708

Sponsor Code (18) DOE/DP,XE
UC Category (19) $U-206, D O E / E R$

DOE 